\title{
Federica Ranzato Santin, Réalisme. Alle origini di una parola moderna
}

\section{Emanuele Kanceff}

\section{(2) OpenEdition}

1 Journals

\section{Edizione digitale}

URL: http://journals.openedition.org/studifrancesi/36577

DOI: 10.4000/studifrancesi.36577

ISSN: 2421-5856

\section{Editore}

Rosenberg \& Sellier

\section{Edizione cartacea}

Data di pubblicazione: 1 juillet 2005

Paginazione: 194

ISSN: 0039-2944

\section{Notizia bibliografica digitale}

Emanuele Kanceff, «Federica Ranzato Santin, Réalisme. Alle origini di una parola moderna», Studi Francesi [Online], 145 (XLIX | I) | 2005, online dal 30 novembre 2015, consultato il 18 avril 2021. URL: http://journals.openedition.org/studifrancesi/36577; DOI: https://doi.org/10.4000/studifrancesi. 36577

Questo documento è stato generato automaticamente il 18 avril 2021.

\section{(c) (1)}

Studi Francesi è distribuita con Licenza Creative Commons Attribuzione - Non commerciale - Non opere derivate 4.0 Internazionale. 


\title{
Federica Ranzato Santin, Réalisme. Alle origini di una parola moderna
}

\author{
Emanuele Kanceff
}

\section{NOTIZIA}

FEDERICA RANZATO SANTIN, Réalisme. Alle origini di una parola moderna, Padova, CLEUP

Editrice (Coll. "Letture e Ricerche Francesi” diretta da Mario Richter), pp. 194.

1 «Raccontare l'avventura di una parola, analizzarla con attenzione dal momento della genesi, seguirla in ogni metamorfosi e rinascita, nelle fasi di successo o di maggior flessione, accingersi insomma allo studio di un vocabolo, potrebbe risultare a prima vista troppo specifico e circoscritto. Dissipare questi timori significa cambiare prospettiva, varcare i limiti che la nostra indagine impone, per soffermarsi sulle possibili conseguenze, per valutare obiettivamente l'effetto di alcuni risultati sulla ridefinizione semantica di altre parole, e, soprattutto, per approfondire il contenuto moderno del termine réalisme».

2 Su tali presupposti, Federica Ranzato studia il passaggio del termine dalla cultura tedesca a quella francese e la sua presenza nei dizionari. Poi ne esamina l'iter tra filosofia e letteratura fino al 1826, anno "della svolta", lo segue nel movimento romantico, nella pittura di Courbet, nel movimento realista di Champfleury, nella rivista «Réalisme», disegnando una convincente progressione attraverso tutto l'Ottocento. Nella conclusione, questo cammino serve a definire gli aspetti del realismo o surrealismo od altre forme correlate nel Novecento. 